\title{
Kualitas Fisik daging Persilangan Ayam Kampung Broiler pada Kepadatan Kandang yang Berbeda
}

\author{
Andi Fausiah, Samsu Alam Rab, Andi Tenri Bau Astuti M
}

Program Studi Peternakan Universitas Al Asyaruah Mandar

*Email: andifausiah31@gmail.com

\begin{abstract}
Abstrak
Tujuan Penelitian Ini untuk menganalisis Kualitas Fisik daging persilangan ayam kampung broiler terhadap tingkat kepadatan yang berbeda. Hasil Penelitian menunjukkan bahwa nilai PH persilangan daging ayam kampung broiler nilai $\mathrm{PH}$ terendah di kepadatan kandang 12 ekor 5,70 dan tertinggi kepadatan kandang 8 ekor 6,21. Daya ikat air untuk kepadatan kandang 8 ekor 33,71 menurun di kepadatan kandang 8 ekor 32,75 dan kembali meningkat di kepadatan kandang 12 ekor 34,93 daya ikat air dipengaruhi oleh nilai $\mathrm{pH}$. Nilai susuk masak tertinngi pada kepadatan kandang 12 ekor yaitu 1,30 dan terendah 1,19 pada kepadatan 10 ekor Daging yang berkualitas mempunyai susut masak yang rendah. Nilai keempukan daging ayam kampung broiler terendah di kepadatan kandang 8 ekor hal ini menyebabkan semakin tinggi kepadatan kandang akan semakin tinggi susuk masak yang capai. Kesimpulan Persilangan ayam kampung dengan ayam broiler dengan kepadatan kandang memberikan pengaruh terhadap PH, Daya Ikat Air dan Tidak berpengaruh Terhadap Keempukan dan Susuk Masak..
\end{abstract}

Kata Kunci : ayam kampung, broiler, kepadatan kandang

\section{Pendahuluan}

Ayam kampung merupakan salah satu jenis unggas lokal yang berpotensi sebagai penghasil telur dan daging sehingga banyak dibudidayakan oleh masyarakat terutama yang bertempat tinggal di wilayah pedesaan. Hal ini disebabkan karena ayam kampung memiliki adaptasi yang baik terhadap lingkungan. Permintaan konsumen akan daging ayam kampung semakin meningkat setiap tahunnya. Berdasarkan data Direktorat Jenderal Peternakan (2014), jumlah produksi daging ayam kampung dari tahun 2007 sampai dengan tahun 2014 terlihat mengalami peningkatan yakni pada tahun 2007 sebanyak 294.889 ton menjadi 332.095 ton pada tahun 2014.

Produksi daging ayam kampung di Indonesia masih tergolong rendah sehingga tidak mampu memenuhi kebutuhan pasar dalam negeri. Penyebab rendahnya tingkat produksi daging ayam kampung karena pertumbuhan ayam kampung yang sangat lambat. Keunggulan ayam broiler yaitu tumbuh dengan cepat dan dipanen dalam waktu yang singkat. Keunggulan genetik yang dimiliki ayam broiler dan pemberian ransum yang baik mampu menampilkan performa produksi yang maksimal dibandingkan dengan ayam kampung. Perbaikan mutu genetik ayam kampung dapat ditingkatkan melalui persilangan ayam kampung dengan ayam broiler parent stockyang diharapkan dapat meningkatkan produksi daging dan tekstur daging yang empuk dengan sistem ketahanan terhadap lingkungan suhu yang tinggi. Persilangan yang dilakukan Daryono et al. (2010) antara ayam pelung dengan ayam broiler parent stock menghasilkan anakan yang memiliki pertumbuhan yang cukup baik. Hasil persilangan memiliki rataan bobot badan pada umur tujuh minggu sebesar 1200 gram.Daging ayam persilangan memiliki kualitas yang lebih baik dibandingkan ayam broiler (Daryono et al. 2012).

Selain genetik, Manajemen perkandangan mempunyai peranan yang besar dalam menentukan performans ayam dan keuntungan. Salah satu hal penting dalam pengelolaan kandang adalah menentukan tingkat kepadatan yang tepat. Namun demikian, belum terdapat informasi mengenai tingkat kepadatan yang optimum untuk pemeliharaan ayam persilangan kampung broiler. Faktor yang menentukan kualitas fisik daging antara lain warna, daya ikat air oleh protein atau water holding capacity (WHC), kesan jus daging (juiciness), tekstur, keempukan, rasa atau flavor, dan nilai $\mathrm{pH}$ daging (Soeparno 2005). Penelitian ini bertujuan untuk menganalisis Kualitas Fisik daging persilangan ayam kampung broiler terhadap tingkat kepadatan yang berbeda. 


\section{Metodologi Penelitian}

Penelitian berlangsung dari bulan April sampai Juli 2019. Penelitian dilaksanakan di Mini Rance Program Studi Peternakan Universitas Al Asyariah Mandar dan Pengujian Kualitas Fisik Laboratorium Teknolohi Hasil Ternak, Universitas Hasanuddin. Alatalat yang digunakan dalam penelitian ini adalah Kandang Pemeliharaan, Tempat Pakan, Tempat Minum, Pisau, timbangan digital, $\mathrm{pH}$ meter, kertas saring, Sampel yang digunakan adalah 9 ekor Persilangan Ayam kampung Broiler umur 12 Minggu yang telah disembeli di Mini Rance Program Studi Peternakan Universitas Al Asyariah Mandar

\section{Hasil Dan Pembahasan}

Kualitas fisik daging merupakan parameter kualitas daging yang terdiri dari nilai $\mathrm{pH}$, susut masak, daya ikat air, dan keempukan daging yang diuji secara obyektif disajikan pada Tabel 1

Tabel 1 Nilai rataan kualitas fisik daging ayam kampung broiler dengan kepadatan kandang berbeda

\begin{tabular}{lccc}
\hline \multicolumn{1}{c}{ Parameter } & $\begin{array}{c}\text { K1 }(8 \\
\text { ekor/m }\end{array}$ & $\begin{array}{c}\text { Kerlakuan } \\
\left.\text { ekor/m } / m^{2}\right)\end{array}$ & $\begin{array}{c}\mathrm{K} 3(12 \\
\left.\mathrm{ekor} / \mathrm{m}^{2}\right)\end{array}$ \\
\hline $\mathrm{pH}$ & $6,21^{\mathrm{a}} \pm 0,07$ & $5,72^{\mathrm{a}} \pm 0,21$ & $5,70^{\mathrm{b}} \pm 0,14$ \\
$\begin{array}{l}\text { Daya Ikat Air } \\
(\%)\end{array}$ & $33,71^{\mathrm{a}} \pm 0,20$ & $32,75^{\mathrm{b}} \pm 0.29$ & $\begin{array}{c}34,93^{\mathrm{c}} \pm 0.3 \\
9\end{array}$ \\
$\begin{array}{l}\text { Keempukan } \\
\left(\mathrm{kg} / \mathrm{cm}^{3}\right)\end{array}$ & $1,19 \pm 0,09$ & $1,27 \pm 0,10$ & $1,30 \pm 0,06$ \\
Susut Masak $(\%)$ & $34,74 \pm 0.36$ & $34,66 \pm 0.37$ & $34,65 \pm 0.32$ \\
\hline
\end{tabular}

\section{- Nilai pH daging.}

Nilai $\mathrm{pH}$ merupakan salah satu faktor penting dalam menentukan kualitas daging, hal tersebut dapat dilihat tabel 1 Hasil Penelitian menunjukkan bahwa nilai PH persilangan daging ayam kampung broiler nilai $\mathrm{PH}$ terendah di kepadatan kandang 12 ekor 5,70 dan tertinggi kepadatan kandang 8 ekor 6,21 hal tersebut memberikan pengaruh yang nyata terhadap kepadatan kandang $(\mathrm{P}<0.05)$. Nilai $\mathrm{pH}$ terkait erat dengan keberadaan mikroba pada daging sehingga sangat menentukan tingkat keawetan dan kualitasnya (Hajrawati et al., 2016). Sesaat setelah penyembelihan, nilai $\mathrm{pH}$ daging akan menurun (Ramli, 2001). hasil ini sesuai dengan penelitian terdahulu, dimana nilai $\mathrm{pH}$ daging berkisar antara 5,82 - 6,79 dan akan terus menurun seiring lamanya penyimpanan (Van Laack et al., 2000; Suradi, 2006; Afrianti, Dwiloka and Setiani, 2013; Hajrawati et al., 2016). Penelitian Mahmud ATBA (2016) nilai PH persilangan Ayam Kampung Broiler sekitar 5,9-6,0 Van Laack et al. (2000) melaporkan nilai $\mathrm{pH}$ daging ayam broiler berkisar antara 5,96-6,07.Daging ayam kampung memiliki nilai pH sekitar 5,91-5,93 (Dewi 2013). Hal ini menunjukkan $\mathrm{pH}$ daging ayam kampung broilermemiliki nilai yang tidak jauh berbeda dengan ayam kampung dan broiler.Nilai $\mathrm{pH}$ daging berpengaruh terhadap daya ikat air. Apabila $\mathrm{pH}$ tinggi maka daya ikat air juga tinggi, begitupun sebaliknya.

\section{- Daya ikat air daging.}

Daya ikat air (DIA) merupakan parameter kualitas daging yang sangat terkait dengan kemampuan air, oleh karena itu daya ikat air berhubungan dengan parameter kualitas. Daya ikat air juga menunjukkan seberapa besar kemampuan daging untuk mengikat air dalam persen. Hasil penelitian menunjukkan bahwa persen daya ikat air untuk kepadatan kandang 8 ekor 33,71 menurun di kepadatan kandang 10 ekor 32,75 dan kembali meningkat di kepadatan kandang 12 ekor 34,93 hal ini memebrikan pengaruh yang berbeda sangat nyata $(\mathrm{P}<0.05)$. Daya ikat air juga dipengaruhi oleh $\mathrm{pH}$ daging (Alvarado dan McKee, 2007), air yang tertahan di dalam otot meningkat sejalan dengan naiknya $\mathrm{pH}$, walaupun kenaikannya kecil. Soeparno (2005) menyatakan bahwa pada $\mathrm{pH}$ yang lebih tinggi atau lebih rendah dari titik isoelektrik protein-protein daging, DIA meningkat, karena pada $\mathrm{pH}$ yang lebih rendah dari titik isoelektrik protein-protein daging, terdapat ekses muatan positif yang mengakibatkan penolakan miofilamen dan memberi lebih banyak ruang untuk molekul-molekul air.

\section{- Susuk Masak}

Susut masak merupakan salah satu penentu kualitas daging yang penting, karena berhubungan dengan banyak sedikitnya air yang hilang serta nutrien yang larut dalam air akibat pengaruh pemasakan. Semakin kecil persen susut masak berarti semakin sedikit air yang hilang dan nutrien yang larut dalam air. Begitu juga sebaliknya semakin besar persen susut masak maka semakin banyak air yang hilang dan nutrien yang larut dalam air Hasil penelitian menunjukkan bahwa persen susut masak daging ayam Kampung Broiler tidak memberikan pengaruh $(\mathrm{P}>0.05)$ terhadap kualitas daging persilangan ayam kampung broiler Daging yang berkualitas mempunyai susut masak yang rendah (Lawrie, 2003; Soeparno, 2005; Dilaga dan Soeparno, 2007) karena kehilangan nutrisi selama pemasakan akan lebih sedikit dan konsumsi pakan dapat mempengaruhi besarnya susut masak (Soeparno, 2005).

\section{- Keempukan}

Keempukan merupakan salah satu kualitas daging yang kritis terhadap daya terima konsumen dan biasanya konsumen menginginkan daging yang empuk (Lawrie 2003). Hasil penelitian menunjukkan nilai keempukan daging ayam kampung broiler terendah di kepadatan kandang 8 ekor hal ini menyebabkan semakin tinggi kepadatan kandang akan semakin tinggi susuk masak yang capai hal tersebut tidak memberikan pengaruh yang nyata terhadap perlakuan $(\mathrm{P}>0.05)$. Hal ini menunjukkan nilai keempukan dari seluruh perlakuan kepadatan kandang tergolong ke dalam kategori empuk dibandingkan ayam kampung. Keempukan daging juga 
dipengaruhi oleh proses pemasakan, yang mengakibatkanprotein myofibril mengalami denaturasi dan koagulasi. Hoffman et al. (2003) melaporkan bahwa nilai $\mathrm{pH}$ daging mempunyai hubungan negatif dengan daya putus daging. Daging dengan nilai $\mathrm{pH}$ tinggi cenderung memiliki nilai daya putus daging yang rendah.

\section{Kesimpulan}

Hasil kesimpulan Persilangan ayam kampung dengan ayam broiler dengan kepadatan kandang memberikan pengaruh terhadap PH, Daya Ikat Air dan Tidak berpengaruh Terhadap Keempukan dan Susuk

\section{Ucapan Terima Kasih}

Ucapan terima kasih kepada Tim Kerja pada Program Studi Peternakan Unasman, LPPM Unasman serta DRPM Kemeristekdikti atas pendanaan tahun 2019 melalui Program Hibah Penelitan Dosen Pemula

\section{Daftar Pustaka}

Afriyanti, M, Dwiloka, B dan Setiani BE. 2013. Total Bakteri, PH dan Kadar Air Daging Ayam Broiler Setelah Direndam Dengan Ekstrak Daun Senduduk (Melastoma malabathricum L.) Selama Masa Simpan. Jurnal Pangan dan Gizi Vol. 04 No.07 Tahun 2013.

Alvarado, C. dan S. McKee. 2007. Marination to improve functional properties and safety of poultry meat.Journal Appl Poultry Res. 16:113120.

Direktorat Jenderal Peternakan dan Kesehatan Hewan (Ditjennak). 2014. Pemerintah Pusat dan Daerah Berkomitmen Melaksanakan Pembangunan Peternakan dan Kesehatan Hewan Nasional. Tersedia : http://ditjennak.pertanian.go.id

Daryono BS, Roosdianto I, Saragih HTSSG. 2010. Pewarisan Karakter fenotip Ayam (F1) Hasil Persiangan Ayam Pelung (Gallus gallus domesticus) dengan Ayam Cemani (Gallus gallus domesticus). Jurnal Veteriner.11(4): 257-273.

Daryono BS, Satriya R, Rohmah Z, Erwanto Y. 2012. Penguatan Industri Bibit Unggas Nasional melalui Produksi Indukan Gama Ayam Lokal Unggul.Jurnal Ilmu Pengetahuan dan Teknologi Tepat Guna. 1(2) : 2089-2721.

Hajrawati, Fadilah, Wahyuni dan Arief. 2016. Kualitas Fisik, Mikrobiologis, dan Organoleptik Daging Ayam Broiler pada Pasar Tradisional. Jurnal Ilmu Produksi dan Teknologi Hasil Peternakan Vol. 04 No. 03; 386-389

Hoffman, D., et al., 2003. Medical Herbalism The Science and Practive at Herbal Medicini. Amerika Serikat: Acts Press. Pp. 90-100

Lawrie, R. A. 2003. Ilmu Daging. Edisi kelima. Universitas Indonesia Press, Jakarta.

Suradi, K. 2006. Perubahan Sifat Fisik Daging Ayam Broiler Post Mortem Selama Penyimpanan
Temperatur Ruang. Jurnal Ilmu Ternak Vol 6 No $1 ; 23-27$

Soeparno. 2005. Ilmu dan Teknologi Daging. Universitas Gajah Mada Press, Yogyakarta

Van Laack, R. L. J. M., C. H. Liu., M. O. Smith and H. D. Loveday. 2000. Characteristics of Pale, Soft, Exudative Broiler Breast Meat. Poultry Sci. 79:1057-1061. 